\title{
Clínica Extensa da Psicanálise, ou Ritual de Cura ${ }^{1}$
}

\section{Leda Herrmann ${ }^{2}$}

Os trabalhos do eixo Psicanálise e suas Clínicas referem a ação da Psicanálise fora das paredes do consultório psicanalítico como uma das nossas possibilidades clínicas. Trata-se da extensão da clínica, tema que foi tratado por Fabio Herrmann, como clínica extensa, em alguns de seus artigos e no livro Fundamentos da Psicanálise: Quatro cursos e um preâmbulo.

Como comentário às apresentações, trago-lhes um relato meu de e em clínica extensa de trabalho desenvolvido por Fabio junto a médicos e alunos de medicina da clínica de gastrenterologia de um hospital escola, no início dos anos 2000. O relato é da mesma época em que esse trabalho foi desenvolvido e é um comentário sobre uma consulta realizado por um médico da clínica, situação da qual também Fabio participava, em um dos anfiteatros da instituição e com a presença, também, de integrantes desse trabalho e alguns convidados. Eu estava no público entre esses convidados.

\section{Ritual de cura}

\section{A propósito do curso sobre a função terapêutica da consulta médica}

Edmilson veio ao anfiteatro contar sua história clínica. Entrou entre tímido, intimidado, mas numa postura ereta, não nos olhava, de vez em quando arriscava o rabo dos olhos. Allan, o médico que o examinaria, acompanhava-o, conduzindo-o de forma solícita. Foi-lhe

\footnotetext{
${ }^{1}$ Este trabalho foi apresentado em oficina sobre as plenárias no I Simpósio Bienal "O mesmo, o outro: Psicanálise em movimento" da Sociedade Brasileira de Psicanálise de São Paulo. 2 Membro Efetivo da SBPSP.
} 
indicado sentar-se de frente para nós, atrás da mesa. O olhar baixo que mantinha desde a chegada volta-se para o médico quando ouve suas primeiras perguntas — nome e local de origem.

“Edmilson." "Do Amazonas."

Começou o relato sobre sua doença do começo. "No dia 24 de abril fez 11 meses que começou". Estávamos em fins de março. Errou o mês, não o período. E o que começou? Uma febre muito alta no dia 24 de abril do ano passado. Enfatiza o "muito alta". Sentia-se muito mal, com calafrios. A febre e o mal-estar obrigavam-no a ir ao pronto-socorro diariamente. Depois de 10 dias, com muita medicação, a febre baixou, mas não o deixou mais, aparece às $8 \mathrm{~h}$ da manhã e desaparece às $3 \mathrm{~h}$ da tarde. Naqueles 10 dias perdeu $9 \mathrm{~kg}$. Do tratamento em pronto-socorro sem que houvesse uma explicação para essa febre, passou por duas internações em diferentes hospitais de Manaus. O que tem, não conseguiram saber. Foi encaminhado para São Paulo.

Estas informações foram a resposta de Edmilson à pergunta de Allan sobre o que sentia. Respondia direta e brevemente às outras perguntas exploratórias do sintoma e voltava à história vivida nos 11 meses. Os exames que não concluíam nada, as conversas com os médicos que também não conseguiam explicar-lhe o porquê da febre. As dores nas costas e nas pernas que foram aparecendo e seu desânimo que foi aumentando. Contando mais a história de sua febre já arriscava olhar-nos. Foi assim que disse ter feito 370 exames de sangue.

Aos poucos, também alguns de nós arriscávamos uma pergunta ou um comentário. Edmilson contando e respondendo nos comunicava que ele é que não conseguia uma resposta. Cada exame não conclusivo significava uma resposta adiada. Quando insistia com os médicos o que ouvia deixava-o mais nervoso. De um ouviu que poderia ser um câncer impossível de detectar, de outra - que comentava o resultado de plaquetas e leucócitos baixos, cujas cifras nos repete — que esses níveis baixando poderia ter uma leucemia. “Minha cabeça fica na lua”, é a expressão que usa mais de uma vez nesse relato. 
Ficamos contaminados por esse não saber. Talvez por isso, nossas perguntas, as da plateia, deixaram um pouco de lado os sintomas. Alguém pergunta se está só em São Paulo, outro, há quanto tempo chegou, outro, sobre sua profissão e trabalho. Edmilson não deixa de referir a doença, os exames, os sintomas, mas mescla em suas respostas outros temas. É militar, está "encostado", a mulher o acompanhou na viagem a São Paulo paga pela Secretaria da Saúde de seu Estado, e aqui permanece, pois recebem uma ajuda de custos. Um pouco mais à vontade conta que telefona diariamente aos filhos, liga a cobrar mesmo sem saber se poderá pagar. A proximidade vai se fazendo entre nós, Edmilson, Allan, plateia. Allan nos olha estimulando nossas perguntas, Edmilson já não mantém o olhar para a mesa. Então alguém pergunta como estava a vida na época do início da doença. Entrecruzando história da doença e história da vida, a pergunta permitiu que nos encontrássemos mais de perto. Edmilson conta que sua vida estava péssima. Ele e a mulher estavam brigando muito, pensando em separação. Neste tempo da doença as coisas foram mudando, o relacionamento melhorando. Mas estava, naquela época, muito difícil, enfatiza.

Ao falar da doença e da vida, da doença em sua vida, vai marcando o tempo desses 11 meses ou com os exames ou com o acréscimo de sintomas, principalmente as dores e desânimo. E é um tempo inconcluso, o resultado esperado quando chega só anuncia um outro exame, uma conclusão para depois, um tempo para depois, para amanhã, e o temor de ser para nunca. É o tempo da angústia.

Já no final do relato, Edmilson pede para contar uma coisa que faz sua cabeça ficar na lua, e que só contou para outros dois médicos, dos muitos por quem passou. A história nos pega a todos. No dia em que a febre apareceu, e ele sabe que foi às $3 \mathrm{~h}$ da tarde, precisava chegar em casa sem vestígios. Sem nenhum cheiro, confirmou respondendo a uma pergunta de um de nós. Eram quase $2 \mathrm{~h}$ da tarde. Teve a ideia de precisar suar muito, para isso fechou as janelas do carro e levou 40m para chegar em casa. Debaixo do sol de Manaus, às $2 \mathrm{~h}$ da tarde, no carro todo fechado, transpirou tudo que era possível, não restou cheiro nem outro vestígio denunciador. Em casa, depois do banho, continuava a transpirar e a sentir muito 
calor, até que colocou o termômetro e constatou febre de mais de $40^{\circ}$. A febre não abaixou com os remédios que tinha em casa, nem com os que mandou comprar por sugestão de amigos. Foi para o pronto-socorro e não mais a febre o deixou, nem a ideia de que teria sido causada por sua atitude, "por isso", que pudemos escutar como: por meu erro, por minha culpa. Pergunta diretamente ao Fabio se essa pode ser a causa da doença, da febre. Escuta atento a resposta de que não é provável ser essa a causa para uma febre de 11 meses, pode ter sido o ponto de partida, o pontapé inicial. Uma dúvida partilhada, uma conversa que deixa de ser solitária no âmbito de sua cabeça, mas conosco conversada.

"Então o que eu tenho? Pensem no meu caso esta noite e vejam se encontram uma resposta". Alguém havia lhe perguntado se ele teria alguma pergunta para nós. Assim responde, assim se despede.

Edmilson, sua doença e sua história, despertou em nós muito interesse. Nós também nos aproximamos emocionalmente dele. Compartilhamos compadecidamente de sua pergunta sem resposta, de seu tempo para depois e de sua angústia.

$\mathrm{Na}$ discussão da consulta, neste caso e nos anteriores, nossa proposta é descobrir a função terapêutica que cumpriu, e se cumpriu. Neste caso vimos que ela atravessou um "ritual de cura", semelhante aos rituais de cura próprios de culturas ditas primitivas. A consulta que perseguiu um dos atratores propostos pelo paciente, imbricamento de sintoma com sua história temporal de um "tempo para depois", e mais o aprisionamento da explicação pessoal que encontrou para a doença, permitiu a Edmilson contato com o proibido - o episódio que o levou à sauna no carro, que ele nem precisou contar. Tocou o real das regras do que um homem responsável pode e não pode fazer, mas propiciando-lhe a representação, até então impossível, talvez por não ter sido escutada, de que esse proibido, motivo de muito culpa, pôde ser compartilhado, ouvido e pensado não mais como sua acusação primordial, mas uma ideia a ser considerada. 
Assim, podemos dizer que esta experiência com Edmilson ou a consulta médica em geral fazem parte do ritual de cura de nossa cultura ocidental "desenvolvida".

\section{Referências}

Herrmann, F. (2005). Clínica Extensa. In A Psicanálise e a Clínica Extensa. São Paulo, Casa do Psicólogo, p. 17-31

(2015). Fundamentos da Psicanálise: Quatro cursos e um preâmbulo. Ed. Blucher, $2^{\mathrm{a}}$ edição. 